금속 패터닝과 Blank노광을 이용한 감광성 유리의 미세가공

조재승 ${ }^{a}$, 강형범 $^{b}$, 윤혜진 $^{b}$, 김효진 $^{b}$, 임현우 $^{b}$, 조시형c, 임실묵 ${ }^{a *}$

a한국산업기술대학교 신소재공학과, ${ }^{b}$ 프로톰(주), ${ }^{c}$ 한양대학교 바이오나노학과

\title{
Microfabrication of Photosensitive Glass Using Metal Patterning and Blank Exposure
}

\author{
Jae-Seung Jo ${ }^{a}$, Hyung-Bum Kang ${ }^{b}$, Hye-Jin Yoon ${ }^{b}$, Hyo-Jin Kimb, Hyun-Woo Limº, \\ Si-Hyeong $\mathrm{Cho}^{\mathrm{c}}$, Sil-Mook Lim $^{\mathrm{a} *}$ \\ ${ }^{a}$ Department of Advanced Materials Engineering, Korea Polytechnic University, Siheung 429-793, Korea \\ ${ }^{b}$ Protom Co., Ltd Gyeonggi-do, Ansan 425-851, Korea \\ 'Department of Bionano Technology, Hanyang University, Ansan 426-791, Korea
}

(Received May 31, 2013 ; revised June 14, 2013 ; accepted June 20, 2013)

\begin{abstract}
The simple and cost-effective microfabrication method of photosensitive glass (PSG) using metal patterning and blank exposure was proposed. Conventional photolithography for micromachining of PSG needs a costly quartz mask which has high transmittance as an optical property. However, in this study the process was improved through the combination of micro-patterned Ti thin film and blank UV exposure without quartz mask. The effect of UV exposure time as well as the DHF etching condition was investigated. UV exposure test was performed within the range from $3 \mathrm{~min}$ to $9 \mathrm{~min}$. The color and etch result of PSG exposed for $5 \mathrm{~min}$ were the most clear and effective to etch more precisely, respectively. The etching results of PSG in diluted hydrofluoric acid (DHF) with a concentration of 5, 10, 15 vol\% were compared. The effect on the side etch was insignificant while the etch rate was proportional as the concentration increased. $10 \mathrm{vol} \%$ DHF results not only high etch rate of $75 \mu \mathrm{m} / \mathrm{min}$ also lower side etch value after PSG etching. This method facilitates the microfabrication of PSG with various patterns and high aspect ratio for applying to advanced applications.
\end{abstract}

Keywords : Photosensitive glass (PSG), Blank exposure, Microfabrication, Glass etching

\section{1. 서 론}

감광성 결정화 유리(photostructurable glass) ${ }^{1,2)}$, 감 광성 식각 유리(photoetchable glass), ${ }^{3,4}$ 로도 불리는 감광성 유리(photosensitive glass: PSG)는 1953년, 미국 코닝사의 Stookey에 의해 보고된 이래5) 다수 의 상업적, 과학적 연구가 진행되어 왔다. 초기에는 감광성 유리 자체에 대한 많은 관심이 집중되었지 만, 최근 microelectronics의 발전과 더불어 소형화,

\footnotetext{
*Corresponding author. E-mail : smlim@kpu.ac.kr
}

고정밀 기계 부품과 기능성 부품에 대한 수요가 맞 물리며, 특수한 용도로 사용하기 위해 다시 주목을 받고 있다.

감광성 유리는 $\mathrm{SiO}_{2}-\mathrm{LiO}_{2}-\mathrm{Al}_{2} \mathrm{O}_{3}$ 계 유리에 감광성을 위해 소량의 $\mathrm{Au}, \mathrm{Ag}, \mathrm{Cu}$ 등 금속을, 광증감제로 $\mathrm{CeO}_{2}$ 를 함유한 유리로, 여기에 자외선을 조사하면 산화환원 반응이 일어나 금속원자가 생기게 되고, 열처리(annealing) 공정을 통해 가열되면서 금속원 자가 응집콜로이드를 형성하는데, 이 콜로이드를 결 정핵으로 결정이 생성되면서 착색되어 유리에 화상 (image)을 나타내게 한다 ${ }^{1-3,6)}$. 이러한 감광성 유리가 
응용되는 가장 큰 이유 중의 하나는 노광부와 비노 광부간의 식각 선택성(etching selectivity)이 매우 크 기 때문에 정밀한 미세구조물의 제작이 용이하다는 점이다. 일반적으로, 감광성 유리는 초순수로 희석 된HF용액에 쉽게 용해되어 식각(etching)이 가능한 데, 자외선이 조사된 노광부는 비노광부에 비해 20 50배 가량 용해속도의 차이가 있는 것으로 알 려져 있다 ${ }^{3,6)}$. 이 용해속도를 적절히 이용하여 선택 적인 식각이 가능하며, 고종횡비를 갖는 정밀한 미 세 가공물을 제작할 수 있다. 또한, 감광성 유리는 우수한 전기절연성, 내열성, 내화학성, 생체적합성 등의 특성을 가지기 때문에 ${ }^{3)}$, 이와 같은 특성을 이 용하여 $\mu$-TAS(total analysis system) ${ }^{7}$, inkjet printer head $^{8)}$, microlens ${ }^{9)}$, microreactor ${ }^{10)}$, micro fuel cell $^{11)}$, MEMS digital accelerometer ${ }^{12)}$ 등 폭넓은 분야에 대 한 연구가 많이 보고되고 있다.

한편, 기존의 감광성 유리를 이용한 미세 구조물 제작에 관한 결과는, 대부분의 논문이 단순한 응용 분야만을 기술하였을 뿐이고, 감광성 기판 자체의 미세 가공에 대한 구체적 방법과 상세한 설명은 매 우 미비하다. 특히, 감광성 유리의 노광 방법은 매 우 중요한데 이는 $270 ~ 330 \mathrm{~nm}$ 파장 범위의 자외선 에서만 반응하는 기판의 특성 때문이다. 이와 같은 특성 때문에 많은 연구자들이 펄스 또는 초단파 레 이저 장비를 사용하여 direct writing 방식으로 기판 을 노광하는 반면 2,4,9,13), 마스크를 필요로 하는 포토 리소그래피(photolithography) 공정에서는 투과율이 높은 quartz 재질의 마스크를 사용함으로써 기판의 노광에 요구되는 파장을 흡수와 반사의 손실없이 효과적으로 전달시킬 수 있다 ${ }^{3,6-8)}$. 그러나, 레이저를 이용한 노광의 경우 레이저 소스와 광학계를 비롯 한 장비의 구축 비용이 매우 고가이며 유지관리가 어렵고, 일반적인 포토리소그래피 공정의 경우 레 이저 사용에 비하여 비용이 적게 소모되고 장비운 용이 간단하지만 다양한 패턴을 제작하기 위해서는 매번 고가의 quartz 마스크의 제작이 요구되어, 감 광성 유리 기반의 다양한 소자 제작에 있어 큰 제 약을 가지고 있다.

이에 본 연구에서는 기존 포토리소그래피 공정과 는 달리 금속층 패터닝 및 blank 노광 공정을 적용 하여 고가의 quartz 마스크를 사용하지 않고, 감광 성 유리 기판에 다양한 미세 구조를 가공할 수 있 는 공정 방법을 제안하였다. 다양한 노광 조건에 따 른 열처리 후 감광성 유리의 착색정도와 패턴의 형 상을 비교하였고, 노광 조건 및 불산의 희석 농도 에 따른 식각 결과를 각각 비교하여 감광성 유리 기판의 미세 가공 공정을 최적화하였다.

\section{2. 실험 방법}

본 연구에서는 가로 $15 \mathrm{~cm}$, 세로 $14 \mathrm{~cm}$, 두께 $500 \mu \mathrm{m}$ 의 사각형 감광성 유리(PEG-3, Hoya, Japan) 를 기판으로 사용하였다. 본 연구에서 수행한 공정 의 개략도를 그림 1 에 나타내었다. 먼저, $\mathrm{SC}-1$ (standard cleaning-1, $\mathrm{NH}_{4} \mathrm{OH}: \mathrm{H}_{2} \mathrm{O}_{2}: \mathrm{DI}$ water $=1: 1: 5$ ) 용액에 기판을 침지한 후 ${ }^{14)}, 80^{\circ} \mathrm{C}$ 의 온도에서 10 분 동안 유지시켜 감광성 유리 기판상의 유기물과 미 세 파티클을 제거하였다. 세정된 기판 위에 자외선 노광시 마스크층으로 사용될 $2000 \AA$ 두께의 $\mathrm{Ti}$ 박 막을 증착하기 위해, 아르곤(Ar) 가스 $30 \mathrm{sccm}$, 공 정압력 $5 \mathrm{mTorr}$, 플라즈마 출력 $300 \mathrm{~W}$ 의 조건에서 스퍼터링(SRN-120, Sorona, Korea)을 실시하였다. 이후, $\mathrm{Ti}$ 박막이 증착된 기판 위에 포토리소그래피 공정을 수행하기 위해 양성 감광액(AZ GXR-601, $\mathrm{AZ}-\mathrm{EM}, \mathrm{USA})$ 을 $3000 \mathrm{rpm}$ 의 속도로 30 초간 스핀 코팅한 뒤, $100^{\circ} \mathrm{C}$ 의 핫플레이트(TH-900, Asone, Japan) 위에서 1 분간 Soft bake하여, 약 $1 \mu \mathrm{m}$ 두께 의 감광층을 형성하였다. 미리 설계된 패턴 도안으 로서 선형 패턴과 원형 패턴이 출력되어 있는 필름 마스크(film mask)를 이용하여 자외선 노광을 실시 하였다. UV 노광장비(MDA-400M, Midas, Korea)를 이용하여 $365 \mathrm{~nm}$ 파장의 자외선을 Hard contact 방 식으로 약 5 초간, 총 $18 \mathrm{~mJ}$ 의 노광에너지를 조사한 뒤, 현상액(AZ300MIF, AZ-EM, USA)에 1분간 침 지하여 감광층에 미세 패턴을 형성하였다. 이렇게

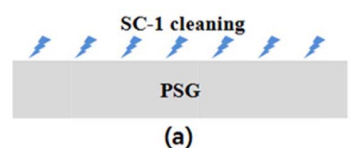

(a)

(c)

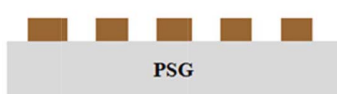

(d)

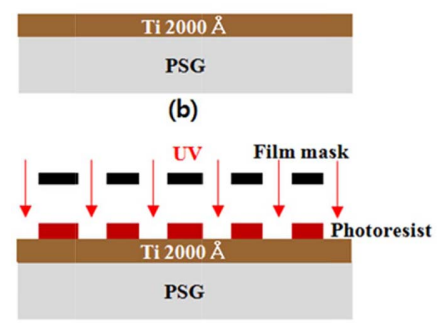

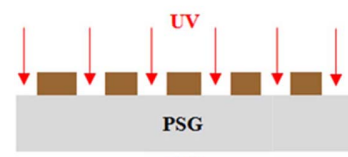

(e)

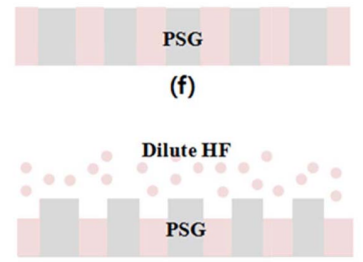

(g)

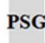

(h)
Fig. 1. Schematic of process flow for micromachining of photosensitive glass (a) substrate cleaning, (b) Ti sputtering $(2000 \AA)$, (c) PR micro-patterning,

(d) Ti wet etching, (e) blank exposure, (f) annealing, (g) DHF wet etching, (h) Final photosensitive glass after micromachining. 
형성된 감광층을 마스크층으로 사용하여 노출된 $\mathrm{Ti}$ 박막을 $\mathrm{Ti}$ 식각액(Ti251, Duksan Chemical, Korea) 에서 약 10 15초간 침지시켜 습식 식각(wet etching) 한 후, 나머지 잔여 감광층은 아세톤 상에서 초음 파를 가하여 박리(strip)하였다. Ti 박막이 패터닝된 감광성 유리 기판을 다시 한번 UV 노광장비에 로 딩하여 별도의 마스크 없이 $3,5,7,9$ 분으로 시간 을 변화시키며 각각 다른 노광에너지(648 1944 mJ) 로 blank 노광을 실시하였다. 노광시간에 변화를 준 이유는 감광성 유리에 열처리 이후 착색의 정도와 에칭 후 미세 구조 관찰을 통해 적정 노광에너지를 확인하여, 노광 공정을 최적화 시키기 위함이다. 또 한, 이 단계에서 패터닝된 $\mathrm{Ti}$ 층은 quartz 마스크 없 이도 선택적인 노광을 가능하게 하는 마스크의 역 할을 한다. 노광 이후, 마스크의 역할을 했던 $\mathrm{Ti}$ 박 막을 $\mathrm{Ti}$ 식각액으로 $10 \sim 15$ 초간 침지시켜 간단히 제 거하였다.

노광이 완료된 감광성 유리 기판을 Furnace(PFD61, P\&Tech, Korea)에 로딩한 후, $2^{\circ} \mathrm{C} / \mathrm{min}$ 의 승온 조건으로 온도를 증가시킨 뒤, 주요 온도 $580^{\circ} \mathrm{C}$ 에 서 2 시간 동안 열처리를 실시하였다. 이후 잔류응 력과 열충격에 의한 파손을 방지하기 위해 Heater 전원을 차단하여 천천히 냉각시켰다. 이렇게 열처 리된 감광성 유리기판에는 $\mathrm{UV}$ 가 조사된 노광부에 선택적으로 결정화가 이루어지게 되며, 이후 초순 수에 불산(HF, 49\%, Duksan Chemical, Korea)을 각각 $5,10,15 \mathrm{vol} \%$ 로 희석한 후, 이 식각액에 기 판을 침지시킨 뒤 초음파를 가하여 5 분간 습식 식 각을 실시하였다. 위와 같은 공정 순서로 미세 가공 된 감광성 유리 기판을 광학현미경(optical microscope, L-150A, Nikon, Japan)과 주사전자현미경(FE-SEM, S-4800, Hitachi, Japan)을 사용하여 비교 분석하였 으며, 접촉식 프로파일러(contact profiler, Dektak$6 \mathrm{M}, \mathrm{Veeco}, \mathrm{USA})$ 을 사용하여 식각된 단차를 측정 하였다.

\section{3. 실험 결과 및 고찰}

그림 2 는 $580^{\circ} \mathrm{C}$ 에서 2 시간 동안 열처리 후 착색 된 감광성 유리 기판의 사진을 보여주고 있다. 일 반적으로 감광성 유리는 광반응을 향상시키기 위해 세륨(Cerium) 원자를 첨가하여 제조하는데, 이 세 륨 원자는 광반응에 의해 $\mathrm{Ce}^{3+}$ 로부터 전자를 방출 하여 $\mathrm{Ce}^{4+}$ 가 되고, 이 때 방출된 전자가 기판 내에 함유된 금속 이온과 결합한 뒤, 이렇게 생성된 금 속 원자들이 응집되면서 형성된 응집체가 최종적으 로 기판 내에서 결정화를 이루어 착색을 일어나게
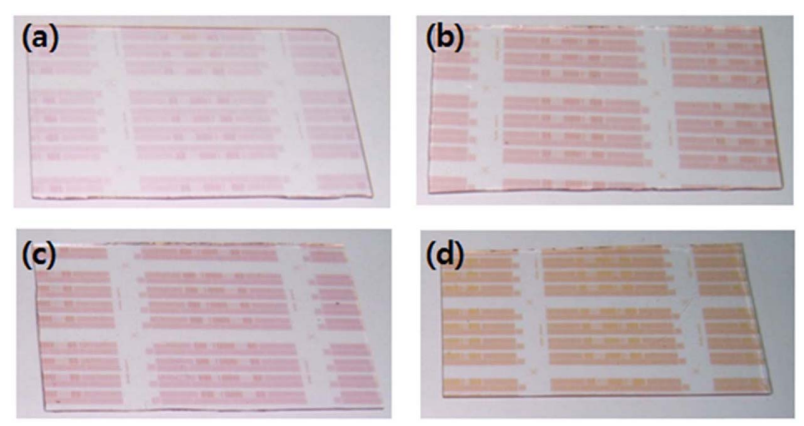

Fig. 2. Photographs of photosensitive glass after annealing at $580^{\circ} \mathrm{C}$ for 2 hours, The color variation is shown as a function of UV exposure time (a) $3 \mathrm{~min}$, (b) $5 \mathrm{~min}$, (c) $7 \mathrm{~min}$, (d) $9 \mathrm{~min}$.

한다 ${ }^{15,16)}$. 따라서 착색되는 정도를 보아 적당한 노 광 시간을 결정할 수 있다. 본 연구에서는 다양한 노광 시간에 따라 열처리 후 착색되는 정도를 비교 하고자 하였다. 그림 2(a)에서와 같이, 3 분(exposure energy : $648 \mathrm{~mJ}$ ) 동안 노광된 시편의 경우 좀 더 길 게 노광된 시편들보다 옅은 붉은색을 보였고, 9분 (exposure energy: $1944 \mathrm{~mJ}$ ) 동안 노광된 시편(그림 2(d))의 경우 다른 시편들에 비해 상대적으로 진한 주황색을 보였다. 5분(exposure energy: $1080 \mathrm{~mJ}$ ) 과 7분(exposure energy: $1512 \mathrm{~mJ}$ ) 동안 노광된 시 편의 경우에는 비슷한 수준의 붉은색을 보여 육안 으로는 큰 차이를 구별하기 어려웠다. 따라서, DHF 용액에서 감광성 유리 시편을 식각한 후, 그 결과 를 확인하여 적정 노광시간을 판단하고자 하였다.

그림 3 은 다양한 조건으로 노광된 시편을 열처리 한 후, $10 \mathrm{vol} \%$ 농도의 DHF 용액에서 2분간 침지 시켜 초음파를 가하면서 식각한 뒤 측정한 광학현 미경 사진이다. 앞서 그림 2(a)에서 3 분간 노광한 후 열처리 뒤에 옅은 붉은색을 보였던 시편의 경우, 그림 3(a)에서와 같이 결정화가 제대로 진행되지 못 하여, 감광성 유리의 식각이 충분히 이루어지지 못 한 것을 확인할 수 있었다. 또한, 그림 2(d)에서 9분 간 노광한 후 열처리를 통해 진한 주황색을 보였던 시편의 경우, 결정화가 과도하게 이루어져 다른 조 건의 시편들에 비해 side etch 효과가 컸음을 확인 하였다(그림 3(d)). 본 논문에서 side etch는 포토리 소그래피에서 사용된 필름 마스크의 최초 패턴 크 기를 기준으로, $\mathrm{DHF}$ 식각 후 기판의 수직이 아닌 수평 방향으로 식각된 길이를 의미한다. Side etch 가 크다는 사실은 노광 에너지가 과도하여 조사되 어 감광성 유리 기판에 실제 제작하고자 하는 패턴 의 크기보다 큰 산란효과가 발생하여, 이에 따라 $\mathrm{Ti}$ 마스크층 하부에 좀 더 넓은 영역으로 결정화가 진 행되어 $\mathrm{DHF}$ 식각 결과 side etch의 증가를 야기시 

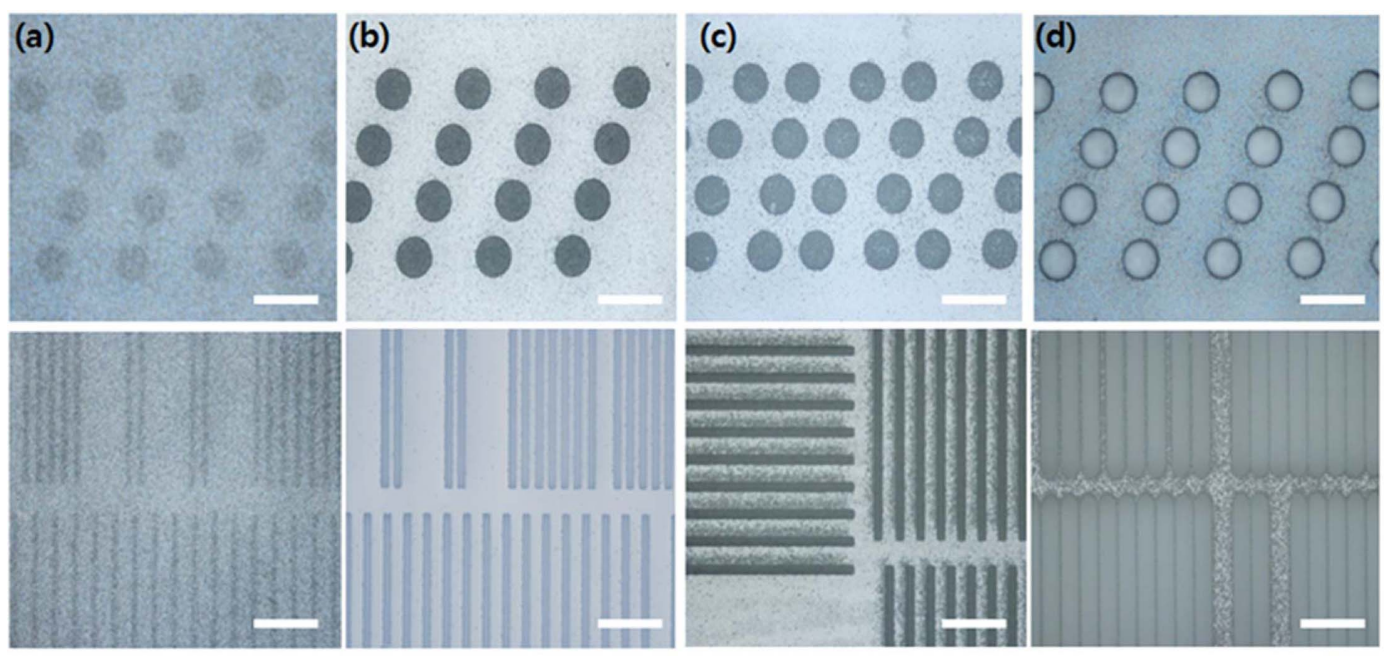

Fig. 3. Optical microscope images of the hole patterns (up) and line patterns (bottom) on photosensitive glass fabricated by whole processes. UV exposure time varied (a) $3 \mathrm{~min}$, (b) $5 \mathrm{~min}$, (c) $7 \mathrm{~min}$, (d) $9 \mathrm{~min}$. Scale bar = $200 \mu \mathrm{m}$.

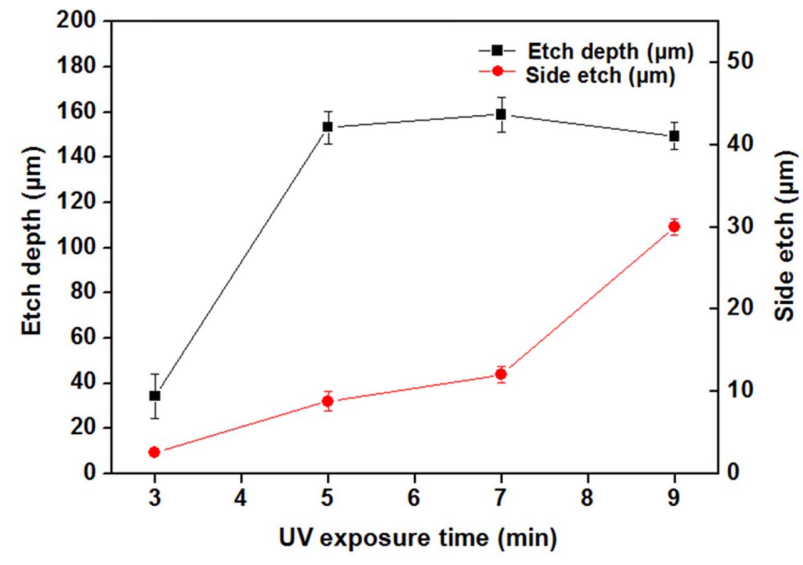

Fig. 4. Etch depth and side etch results of photosensitive glass as a function of UV exposure time. All the samples were etched in $10 \mathrm{vol} \% \mathrm{DHF}$ for $2 \mathrm{~min}$ after annealing at $580^{\circ} \mathrm{C}$ for 2 hours.

켰다고 이해할 수 있다. 한편, 그림 2(b)와 그림 2(c) 에서 착색된 색깔만으로는 판단할 수 없었던 적정 노광 조건을 그림 3(b)와 그림 3(d)를 통해 확인할 수 있었다. 5 분간 노광된 시편의 경우, 7 분간 노광 된 시편에 비해 식각된 원형 및 선형 패턴의 윤곽 이 더욱 선명하였다.

적정 노광 시간을 5 분으로 결정함에 있어, $\mathrm{DHF}$ 식각 결과에서 또한 그 이유를 뒷받침 할 수 있다. 그림 4는 접촉식 프로파일러(contact profiler)를 사 용하여 네 개의 시편에 대한 패턴 단차와 선폭을 측정한 뒤, 각 시편의 식각 깊이(etch depth)와 수평 식각(side etch) 수치를 그래프로 나타내 주고 있다. 식각 깊이는 감광성 유리의 미세가공 공정에 있어 식각률을 판단하는 중요한 지표이고, 수평 식각 결
과는 이방성 식각의 정도를 결정하며, 고종횡비 미 세구조를 제작하는 데에 있어 참고할만한 중요한 지표이다. 전체적으로 볼 때, 결정화가 충분히 되지 못해 식각이 느리게 진행된 3 분간 노광된 시편의 경우를 제외한, 5 분 9 분 노광 시편에서는 약 150 $160 \mu \mathrm{m}$ 의 비슷한 수준의 식각 깊이가 측정되었다. 그러나 수평 식각의 경우, 5 분간 노광된 시편이 더 오래 노광된 시편들에 비해 상대적으로 낮은 수치 의 결과를 보였고, 이는 5 분의 노광 조건이 감광성 유리 기판을 효과적으로 미세 가공하는 데에 유리 하다는 사실을 뒷받침해 줄 수 있다.

다음으로 본 연구에서는, 다양한 $\mathrm{DHF}$ 농도가 감 광성 유리 기판의 식각에 미치는 영향에 대해 알아 보고자 하였다. 이를 위해, 5 분간 자외선을 노광시 킨 시편을 $580^{\circ} \mathrm{C}$ 에서 2 시간 동안 열처리한 후, $5 \mathrm{vol} \%, 10 \mathrm{vol} \%, 15 \mathrm{vol} \%$ 의 세 종류의 농도로 준비 된 $\mathrm{DHF}$ 용액에 침지시켜 각각 5 분간 초음파를 가 하면서 식각하고, 식각된 샘플을 앞서 언급한 동일 한 방법으로 측정하여 식각률과 수평 식각 결과를 각각 비교해보았다. 그림 5는 세 가지 농도의 DHF 에서 식각된 감광성 유리 기판의 식각률과 수평 식 각 수치를 그래프로 보여주고 있다. 식각률은 DHF 농도가 높을수록 증가하는 것을 확인하였는데, 이 는 자연스러운 현상으로서 $\mathrm{HF}$ 함량이 높아질수록 식각에 주요하게 관여하는 silicate와 $\mathrm{HF}$ 간의 용해 반응이 활발해지기 때문이다 ${ }^{3)} .10 \mathrm{vol} \%$ 와 $15 \mathrm{vol} \%$ $\mathrm{DHF}$ 용액의 감광성 유리 식각률은 각각 $75 \mu \mathrm{m} / \mathrm{min}$, $110 \mu \mathrm{m} / \mathrm{min}$ 으로 매우 높은 식각률을 확인할 수 있 었다. 여기서 또한 주목해야 할 점은, 기존의 유리 기판에 마이크로 단위의 이방성(anisotropic) 식각을 


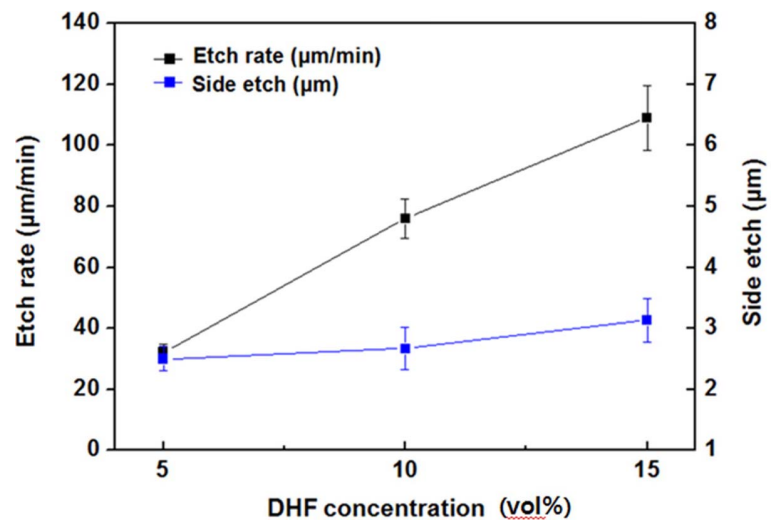

Fig. 5. Etch rate and side etch results of photosensitive glass as a function of DHF concentration (a) 5 vol\%. (b) 10 vol\%, (c) 15 vol\%. All the samples were etched for $5 \mathrm{~min}$.

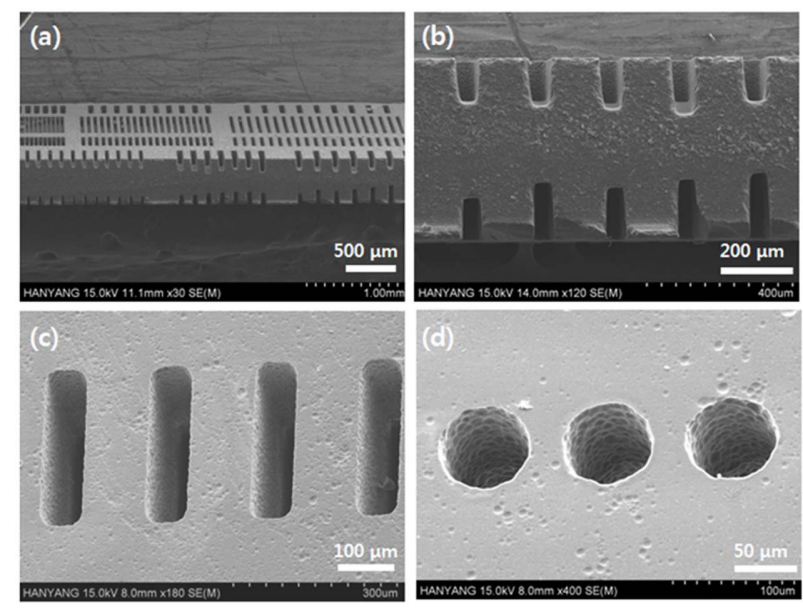

Fig. 6. FE-SEM images of microfabricated photosensitive glass (a-c) line array with a width of $75 \mu \mathrm{m}$, (d) hole patterns with a diameter of $50 \mu \mathrm{m}$.

수행함에 있어 가장 큰 제약이었던 매우 낮은 식각 률에 비하여, 감광성 유리를 활용하면 매우 짧은 시 간에 고종횡비의 이방성 식각을 가능하게 할 수 있 다는 것이다. 이러한 점은 감광성 유리를 초정밀 부 품으로 응용하게 하는 주된 이유이기도 하다. 그러 나, 그림 5에서 수평 식각 결과를 살펴보면 $\mathrm{DHF}$ 의 농도와는 큰 관련 없이 2.7 3.1 $\mu \mathrm{m}$ 정도의 범위에 서 비슷한 경향을 보였는데, 이 결과는 그림 4 의 결과와 비교했을 때 자외선 노광 조건이 수평 식각 결과에 미치는 영향력이, DHF 농도가 수평 식각 결과에 미치는 영향력보다 더욱 지대하다는 사실을 설명해주고 있다.

그림 6에서는 본 연구를 통해 개발된 금속 박막 패터닝 및 blank 노광을 이용한 감광성 유리 미세 가공의 최적 조건으로 제조된 다양한 시편의 $\mathrm{FE}-$ $\mathrm{SEM}$ 사진을 보여주고 있다. 그림 $6(\mathrm{a})$ 는 $75 \mu \mathrm{m}$ 의
선폭을 갖는 line 패턴을 식각하여 제작한 구조이 며, 그림 6(b)는 같은 시편을 절단하여 횡단면을 측 정한 사진이다. 기판의 양면에 형성된 마이크로 채 널의 깊이가 균일하지 않은데, 이는 식각하는 장비 를 개선하여, 식각 균일도를 증가시켜야 할 것으로 사료된다. 그림 6(c)와 그림 6(d)는 $75 \mu \mathrm{m}$ 선폭의 line 패턴과 $50 \mu \mathrm{m}$ 지름의 원형 패턴 구조를 각각 측정한 사진으로서, 이는 차후 다양한 모양의 미세 패턴을 제작하는 데에 본 연구에서 제안된 공정이 적용될 수 있는 가능성이 충분하다는 사실을 뒷받 침해 준다.

\section{4. 결 론}

본 연구에서는 고가의 quartz 마스크의 사용 없이 도 감광성 유리를 다양하게 미세가공 할 수 있도록 금속 패터닝과 blank 노광을 접목한 감광성 유리의 미세가공 공정을 개발하였다. 이와 동시에 시편 가 공에 적절한 노광 조건을 알아보기 위해, 자외선 노 광 시간을 변화시키면서 그에 따른 착색 정도와 식 각 결과를 비교 분석하였다. 또한, DHF 농도가 감 광성 유리 기판의 식각에 미치는 영향을 알아보기 위해 다양한 농도의 조건에서 시편을 식각한 후 식 각률과 수평 식각 결과를 비교하였다. 그 결과, 5 분 (노광 에너지 $1080 \mathrm{~mJ}$ )의 자외선 노광과 열처리 이 후 $10 \mathrm{vol} \%$ 농도의 DHF 용액에서 초음파를 가하 여 식각하는 공정 조건이 감광성 유리 기판을 정밀 하게 이방성으로 가공하는 데에 가장 효과적인 것 으로 확인하였다. 본 연구에서 제안된 공정을 이용 한다면, 간단하면서도 경제적으로 감광성 유리를 이 용한 다양한 미세 구조를 제작하는 데에 활용할 수 있을 것으로 기대된다.

\section{References}

1. H. Becker, M. Arundell, A. Harnisch, D. Hülsenberg, Sens. Actuators B, 86 (2002) 271.

2. F. E. Livingston, P. M. Adams, H. Helvajian, Appl. Surf. Sci., 247 (2005) 526.

3. T. T. Dietrich, W. Ehrfeld, M. Lacher, M. Krämer, B. Speit, Microelectron. Eng., 30 (1996) 497.

4. M. Kösters, H.-T. Hsieh, D. Psaltis, K. Buse, Appl. Opt., 44 (2005) 3399.

5. S. D. Stookey, Ind. Eng. Chem., 45 (1953) 115.

6. H.-J. Kim, S.-H. Lee, S.-J. Yon, S.-C. Choi, J. Korean Cream. Soc., 37 (2000) 82.

7. S. Etoh, T. Fujimura, R. Hattori, Y. Kuroki, Microsyst. Technol., 9 (2003) 541.

8. U. Brokmann, K. Sönnichsen, D. Hülsenberg, 
Mircosyst. Technol., 14 (2008) 1635.

9. C. H. Lin, L. Jiang, Y. H. Chai, H. Xiao, S. J. Chen, H. L. Tsai, Appl. Phys. A, 97 (2009) 751.

10. T. R. Dietrich, A. Freitag, R. Scholz, Chem. Eng. Technol., 28 (1005) 477.

11. T. Ito, M. Kunimatsu, Electrochem. Commun., 8 (2006) 91.

12. U. Park, K. Yoo, J. Kim, Sens. Actuators A, 159 (2010) 51.
13. Z. Wang, K. Sugioka, K. Midorikawa, Appl. Phys. A, 89 (2007) 951.

14. P. J. Resnick, C. L. J. Adkins, P. J. Clews, E. V. Thomas, N. C. Korbe, Mater. Res. Soc. Symp. Proc., 386 (1995) 21.

15. U. Kreibig, Appl. Phys., 10 (1976) 255.

16. S. D. Stookey, G. H. Beall, J. E. Pierson, J. Appl. Phys., 49 (1978) 5114. 